\title{
Application of Fair Value Measurement in China: Problem and Prospect
}

\author{
Liu Xuexin ${ }^{1, \text { a }}$, Yuan Jiayi ${ }^{2, b}$ \\ ${ }^{1}$ College of Business Administration, Capital University of Economics and Business ,Beijing , China \\ ${ }^{2}$ College of Business Administration, Capital University of Economics and Business ,Beijing, China \\ aliuxuexin@cueb.edu.cn, bdaisy_9128@163.com
}

Keywords: fair value; measurement; application; prospect; perfection

\begin{abstract}
Fair Value has been taken very seriously around the world since its potential high relevance. China has widely introduced the measurement attributes to the new measurement methods. Large amount of enterprises went bankrupt or suffered capital decrease during financial crisis because of the utilization of Fair Value Measurement, which caused many negative discussions about Fair Value Measurement. To make the concept of Fair Value Measurement acceptable by more people and correctly practical in the background of increased extent of application of Fair Value Measurement, this research mainly described the problems related to the application of Fair Value Measurement in China and give an outlook about it.
\end{abstract}

\section{Introduction}

With China's booming technology and the spring up of finance and market innovation, historycost-measurement-centered single accountancy measurement model cannot acclimatize itself to the demand of knowledge economics age. Fair Value has been paid high attention by many countries and regions in the world because of its potential high relevance. In the process of China's enterprises participating economical globalization, the international tendency of accountancy norm directly affect China's economic status. It's very important to widely bring in Fair Value's measurement attributes which both maintained a higher coordination with international accountancy norm and take China's national condition into consideration.

\section{Application Status of The Fair Value in China}

China first introduce fair value in 1998 since fair value Measurement can provide more related accountancy information than history cost measurement which can help the decision maker choose right decisions. Because of the lack of active market in China, Fair Value are always hard to obtain, which make the application of this accountancy norm by enterprises more casual, and lots of companies start to utilize fair value to transfer capital or manipulate profits, however it has been restricted for use in the norm modified by financial department in 2001. As knowledge economics age coming, intangible assets emerging in company and massive use of derivative financial instruments, customers need more relevant information to evaluate both the opportunity and risks they are about to confront with and the information users have increased the relevance requirement of accountancy information. Meanwhile, for the sake of promoting our country's economy connected with international standard, financial department formally published enterprises accountancy norm system in Feb $15^{\text {th }}$ 2006, one of whose characteristic is massive application of fair value.

\section{Problems existed in China's application of Fair Value}

Nowadays, fair value measurement is still in a low-level stage in China. Fair value theory's study is not perfect and accounting personnel's professional skills need to improve. There are still some problems in the practical use of fair value measurement. 


\section{A. Poor Maneuverability}

- Poor valuation technique

Since the essence of fair value is the objective affirmation from fair trade market to assets or liabilities, the fair value mainly come from a comparatively objective estimate from market to the value of assets or liabilities, which means fair value shows as a kind of estimated price. When apply valuation technique to estimate relevant assets or liabilities' fair value, present value always comes to be a more common estimate method. Because of the expected returns and valuation modeling differences both among investors and between investors and administering authority, however, there are greater uncertainties about the future cash flow which would cause inequities, incomparableness and misguidance toward investors and would highly increase the difficulty for accountant to confirm the fair value.

- Higher cost for fair value measurement's application

It's difficult to obtain relevant fair market value since our nation's undeveloped economy, inactive market transactions, small financial market and not usually used financial tools at this period. Meanwhile, enterprises accountant need to analyze every aspect of each final accounting during the period of initial and follow-up measurement so that they can make a new affirmation about the fair value of assets and liabilities, which needs a large number of data and information and a higher demand about technique and personnel, which will certain cause the cost of accounting measurement and financial management. However, the utilization of fair vale has also increased the risk of financial report, a higher requirement toward relevant supervision department such as auditing office and CPA and the cost of auditing cost. Besides, lots of affirmation about fair value in China's accounting practice now relies on evaluation made by intermediary such as accounting firm and assets evaluation agencies, which lead to a higher cost of affirmation of fair value.

\section{B. Fair value measurement's impact on the quality of financial information}

- The application of fair value measurement may cause false scent of poor company operation.

Using fair value measurement model, the changes in assets and liabilities will be included in the net assets or net profits and losses, which can lead to the enterprise the management earnings volatility. The shares of listed companies, for example, under the historical cost measurement model, before selling the market price fluctuations don't adjust the book value is not included in the current profits and losses, unless the final market price is below cost; And under the fair value measurement model, economic environment and risk situation of change and the change of the enterprise itself the credit, can cause the fluctuation of corporate financial statements, lead to business performance of high and low, enterprise management to investors due to the unstable phenomenon, and may even mislead users of financial statements, affect the enterprise value.

- Application of fair value measurement may cause loss of reliability of financial information

First of all, it would easily cause profit manipulation and accounting information distortion. The reliability of fair value has been the focus of question since fair value was introduced into accounting practice. When active markets exist, fair value measurement bases on market direct observational quoted prices whose reliability should not be questioned. The question is fair value measurement requires subjective judgment and has manipulative space.

Furthermore, fair value measurement would cause pro-cyclical effect and excessive underestimate about financial value in crisis environment. Financing institute would write down the financial assets according to market price when market crash or lose its basic function, which would cause decrease of both enterprise physical count quantity and capital adequacy ratio. At this time, because of the deterioration of debtor's cash flow condition, investors undersell their shares in panic leads to a sharp decrease of fair value, which would make the recoverable amount far below book value and company has to withdraw large amount of provision for diminution in value. Increased losses, in turn, promote the enterprises and financial institutions to intensify efforts to sell existing assets. In addition to the direct cost caused by low price undersell, surplus 
assets have to step into the vicious circle of consecutive plummet of trade prices because of the market price plummet which would further cause withdrawing decrease.

\section{Suggestions}

\section{Improve the maneuverability}

- Strengthen the theoretical study, Provide valuation guides and improve the valuation technique.

To use the fair value reasonably, we should strengthen its theoretical study, improve the theoretical system and build a framework that suite for China's national conditions. This framework should explain the detail of fair value so that make it easy to manipulate.

The current norm is lake of the necessary valuation guide, however accountants' capacities are limited, it's very critical to provide corresponding valuation guide. The valuation guide should provide selectable valuation models and applicable conditions for different models to reduce the arbitrariness. The guide should also clear that if there are many models for available, enterprises should use multiple models to test the price. At the same time, the guide should include some examples of how to choose the relevant parameters and models and ask enterprises to verify the relevant parameters and models in order to ensure that the relevant parameters and models reflect the market value.

- Improve accountants’ occupational judgment and professional level

Using fair value is limited by the accounting standards and accountants' occupational judgment. Apparently, our accountants' occupational judgment can't meet the requirements. We can see it from the problem during using it. So improve the whole level of accountants' occupational judgment is very important. First, strengthen accountants' professional knowledge through training. Helping them familiar with and master the methods and procedures. Accountants must have the ability to recognize the valuable information from lots of complex information. Second, accountants need to broaden their horizons, should not be limited to the business of their own company. They should try to know the characteristics of their profession and the performance of other relevant companies. Third, we should strengthen accountants' professional ethics and the awareness of integrity.

\section{To reduce the impact of the fair value measurement on the quality of financial information}

- To reduce the impact of the fair value measurement on the quality of financial information

We should provide the historical cost measures and fair value measures at the same time on two types of financial reports respectively to reconcile contradiction. Firstly, we can set two measurement models at the same time. Secondly, we should conduct daily accounting work in historical cost and don't use fair value for daily accounting. Finally, we should provide two types of financial reports at the end of each accounting period.

- Measures to prevent that using of fair value measurement attributes to manipulate profits

The most pivotal measure is to strengthen the supervision of the fair value measurement, establishing a impeccable fair value auditing system. Enterprises should be impelled to use fair value measurement correctly.

Strengthen the specification of the laws and regulations for operational behavior, ensuring the reliability of accounting information. Further, we should improve the existing laws and regulations to provide a good legal environment for the implementation of the fair value. China should complete a set of specific audit guidelines for the fair value timely, standardizing the determination procedures of fair value. At the same time, strengthen the supervision and management of the accounting staffs, making accounting staffs abide by professional ethics strictly when they use the fair value measurement.

- The measures of Reducing Pro-cyclicality caused by fair value

In order to alleviate the effect of pro-cyclicality caused by fair value, you could use the uniform pricing service to obtain the fair value of related financial products. Uniform pricing is a 
quote service that is provided by the independent brokers and consultants for the complex and illiquid financial instrument. The price is based on the selling price of related financial instrument, however, if the value of the financial instruments are too scattered or the banks believe the value is not fully reflected in the market, the result of uniform pricing maybe not correct. So when using the uniform, you needs to assess the authenticity and authority of brokers and consulting agency's price level, and ensure whether the pricing mechanism of quote price they provided are in line with fair value measurement or not.

\section{Conclusion}

The emergence and use of the fair value conforms to the needs of economic development. Although there are a number of difficulties and obstacles with widespread of fair value in China, the development and application of fair value has become an irresistible trend. At present, we need to fully understand the fair value, understanding the obstacles we faced, finding the solutions, and then we can gradually improve the theoretical system of the fair value in practice, establishing the accounting standards that similar to the international norms, further improving the market economy system, perfecting the system of legal norms, strengthening supervision. Use these to guide practice, and finally making the fair value gradually matured.

\section{Acknowledgment}

This paper is supported by Humanities and Social Sciences Planning Fund of Chinese Ministry of Education (08JA790087), Beijing Municipal Natural Science Foundation (9112003) and Beijing Social Science Foundation (12JGA007).

\section{References}

[1] Li Fei and Liu Ying Ming: Fair value measurement in a market that is not active- - The analysis of fair value under the background of financial crisis, China Management Informationization, vol 4 ,p.18-20.(2011)

[2] Zhang Yongze: The Problem and Countermeasures in the Application of Fair Value, China Township Enterprises Accounting , vol 3,p.38-39.(2010)

[3] Jiang Xuerong: Financial Crisis, and the Application Analysis of the Fair Value Measurement Accounting in China, Charming China, vol 7,p.86-87.(2010)

[4] Liu Jing and Ding Chunling: The Improvement Measures of the Fair Value Measurement From the Financial Crisis, Commercial Times, vol 15,p.74-75.(2010)

[5] Wu Fengxia: The Discussion of the Obstruction and Countermeasures of Fair Value Measurement, Contemporary Economics, vol 10,p.100-101.(2010)

[6] Zhou Gongming: The Pro-cyclicality and Improvement Measures of the Fair Value AccountingBased on the perspective of financial crisis, Economy and Management, vol 1,p.64-67.(2010) 